\title{
Focal Adhesion Kinase Regulates Neuronal Growth, Synaptic Plasticity and Hippocampus- Dependent Spatial Learning and Memory
}

\author{
Francisco J. Monje ${ }^{a}$ Eun-Jung Kim ${ }^{a}$ b Daniela D. Pollak ${ }^{a}$ Maureen Cabatic $^{a}$ \\ Lin Li $^{\mathrm{b}}$ Arthur Baston ${ }^{\mathrm{a}}$ Gert Lubec ${ }^{\mathrm{b}}$ \\ a Department of Neurophysiology and Neuropharmacology, Center for Physiology and Pharmacology, and \\ ${ }^{\mathrm{b}}$ Department of Pediatrics, Medical University of Vienna, Vienna, Austria
}

\section{Key Words}

Focal adhesion kinase $\cdot$ Neurotrophic tyrosine kinase

receptor type 1 TrkA $\cdot$ Hippocampus $\cdot$ Long-term

potentiation $\cdot$ Learning and memory

\begin{abstract}
The focal adhesion kinase (FAK) is a non-receptor tyrosine kinase abundantly expressed in the mammalian brain and highly enriched in neuronal growth cones. Inhibitory and facilitatory activities of FAK on neuronal growth have been reported and its role in neuritic outgrowth remains controversial. Unlike other tyrosine kinases, such as the neurotrophin receptors regulating neuronal growth and plasticity, the relevance of FAK for learning and memory in vivo has not been clearly defined yet. A comprehensive study aimed at determining the role of FAK in neuronal growth, neurotransmitter release and synaptic plasticity in hippocampal neurons and in hippocampus-dependent learning and memory was therefore undertaken using the mouse model. Gain- and loss-of-function experiments indicated that FAK is a critical regulator of hippocampal cell morphology. FAK mediated neurotrophin-induced neuritic outgrowth and FAK inhibition affected both miniature excitatory postsynaptic potentials and activity-dependent hippocampal long-term poten-
\end{abstract}

\section{KARGER}

Fax +41613061234 E-Mail karger@karger.ch www.karger.com



tiation prompting us to explore the possible role of FAK in spatial learning and memory in vivo. Our data indicate that FAK has a growth-promoting effect, is importantly involved in the regulation of the synaptic function and mediates in vivo hippocampus-dependent spatial learning and memory.

Copyright $\odot 2011$ S. Karger AG, Basel

\section{Introduction}

Activity-related neuritic and synaptic growth is a fundamental mediator of the functional strengthening of synapses mediating the formation and storage of longterm memories [1]. Several different signaling cascades are known to contribute to the regulation of learningrelated synaptic plasticity, including receptor tyrosine kinases mediating the actions of neurotrophins $[2,3]$ as well as non-receptor tyrosine kinases [4-6]. The focal adhesion kinase (FAK), a non-receptor tyrosine kinase, is highly expressed in the nervous system and particularly enriched in the cortex and in the hippocampus $[7,8]$,

\section{F.J. Monje and E.-J. Kim contributed equally to the work.}

Prof. Dr. Gert Lubec

Department of Pediatrics, Medical University of Vienna

Währinger Gürtel 18-20

AT-1090 Vienna (Austria)

Tel. +43 140400 3215, E-Mail gert.lubec@ meduniwien.ac.at 
brain regions with pivotal importance for learning and memory. FAK has been proposed to mediate neuronal outgrowth and modulate synaptic plasticity, processes importantly involved in the neurobiological mechanisms underlying learning and memory [9]. However, the specific contribution of FAK to the molecular pathways underlying neuronal growth, synaptic function and plasticity remains poorly understood. In fact, conflicting data regarding its role as regulator of neuritic outgrowth have been reported.

For example, it has been shown that cell-specific ablation of FAK increases the number of axonal terminals and synapses formed by neurons in vivo and induces a greater number of axonal branches in culture, indicating FAK as a negative regulator of axonal branching and synapse formation [10]. In contrast, more recent studies suggest that FAK promotes neuritic extensions, possibly through inhibition of ATP-gated P2X7 receptors [11]. Similarly, it has also been shown that the leucine-rich repeat protein netrin recruits and activates FAK and requires FAK function for mediating its effects on axonal guidance and outgrowth [12]. Costimulation of integrins and growth factor receptors also activates proteins of the FAK family to promote neuritic outgrowth and expression of the C-terminal domain of FAK is sufficient to block neurite outgrowth [13]. Since these observations support a positive neurite-promoting effect of FAK in neurons, it is plausible to speculate that FAK might have a dual role depending on the type of cell, the associated proteins or on the mechanisms of activation. For example, the relevance of FAK as a downstream effector of EphB receptors and the importance of FAK to maintain mature dendritic spines by regulating cofilin activity has been demonstrated [14]. Additionally, treatment of hippocampal slices with ephrin-A3 has been demonstrated to decrease FAK and it has been proposed that FAK might be related to the maintaining of proper spine morphology [15]. On the other hand, Moeller et al. [16] showed hat FAK activation is important for spine shortening and morphogenetic changes also downstream of EphB receptors in cultured hippocampal neurons.

To better understand the role of FAK in learning-related modulation of synaptic growth and function, we have undertaken a systematic study of its role in neuronal growth as well as in the synaptic activity and plasticity of hippocampal neurons and evaluated its importance for learning and memory in vivo. First, we studied the relevance of FAK for the neuritic outgrowth of hippocampal neurons in culture using loss-of-function and gain-offunction (FAK overexpression) approaches. For loss of function we used both a pharmacological and a genetic strategy. For pharmacological inhibition we used the specific FAK inhibitor 1,2,4,5-benzenetetraamine tetrahydrochloride (also known as Y15). For loss-of-function experiments using a genetic strategy we performed transfections of FAK shRNA following an approach that has been successfully used previously [17-21]. The small molecule inhibitor Y15 has been very recently described as a very powerful, specific and selective inhibitor of the FAK which also targets the position Y397 of the protein [2225]. The Y15 molecule was identified by a combined informatics modeling/screening, pharmacological and molecular-biological approach [22-25]. The remarkably selective inhibitory properties of this molecule, which has already been tested in human cells, makes it a promising tool for therapeutic interventions against several forms of cancers, as Y15 can specifically inhibit the activity of tumor cell FAK resulting in inhibition of tumor cell adhesion and tumor regression in vivo [22-25].

Second, we investigated the involvement of FAK in the spontaneous and neurotrophin-induced neurotransmitter release at hippocampal synapses. Third, we defined the role of FAK in long-term potentiation (LTP) in acute hippocampal slices and as a final point evaluated its contribution to hippocampus-dependent learning and memory at the behavioral level in mice. We found that FAK positively modulates both neuritic outgrowth and synaptic plasticity and is importantly involved in the formation and retention of long-term spatial memory.

\section{Materials and Methods}

\section{Animals and Housing}

Adult C57Bl/6J male mice (Janvier, France), 10-12 weeks old, were housed in pairs in standard transparent laboratory cages in a temperature-controlled colony room $\left(21 \pm 1^{\circ} \mathrm{C}\right)$ and were provided with food and water ad libitum. Mice were maintained on a 12-hour light/dark and cages were cleaned once a week. All animal experiments are in line with the UK Animals (Scientific Procedures) Act, 1996 and associated guidelines (86/609/EEC) and were approved by the local animal committee.

\section{Hippocampal Culture}

Postnatal mouse (days 0-3) hippocampal neurons were dissociated and cultured following standardized procedures [26] and complemented with glial support cultures as previously described [27].

\section{Morphological Evaluation}

On the day of plating (day 0), cells were untreated (control), incubated with $1 \mu \mathrm{M}$ Y15 (Sigma-Aldrich, Austria), incubated with neuronal growth factor (NGF) $(25 \mathrm{ng} / \mathrm{ml})$ or incubated with NGF $(25 \mathrm{ng} / \mathrm{ml})$ in the presence of $1 \mu \mathrm{M}$ Y15. Morphological anal- 
ysis was carried out $24 \mathrm{~h}$ after addition of the respective cell treatment. Images were acquired using Axiovert 200M (Zeiss) and analyzed using ImageJ software (http://rsbweb.nih.gov/ij/). Neuritic outgrowth was evaluated according to parameters described elsewhere $[28,29]$. For transfection of hippocampal neurons, $1 \mu \mathrm{g}$ of each DNA (GFP plasmid and FAK-GFP plasmid) was incubated with $15 \mu \mathrm{g}$ of Nupherin-neuron (Nupherin ${ }^{\mathrm{TM}}$ Transfection Reagent; ENZO Life Sciences) in $150 \mu$ l of neurobasal medium without antibiotics for $15 \mathrm{~min}$. In parallel, $1 \mu \mathrm{l}$ of Lipofectamine ${ }^{\mathrm{TM}}$ LTX Reagent (Invitrogen) was separately mixed in $150 \mu$ l of neurobasal medium. After $15 \mathrm{~min}$, the two solutions were combined (mix) and incubated for $45 \mathrm{~min}$. Cell culture media was removed (and stored at $37^{\circ} \mathrm{C}$ ) and neurons (cultured in 24-well plates) were incubated in the $300 \mu \mathrm{l}$ of mix for $5 \mathrm{~min}$, centrifuged (in a swinging bucket centrifuge) at $233 \mathrm{~g}$ for $5 \mathrm{~min}$ and additionally incubated for $2.5 \mathrm{~h}$. The mixture was then removed and replaced with the original cell culture media and neurons continued in culture until experiments were performed. This transfection procedure was also used to transfect specific FAK shRNAs (Santa Cruz) in order to inhibit FAK expression as previously described [17-21]. For this, coexpression experiments were carried out combining GFP and FAK shRNAs $(0.5 \mu \mathrm{g}$ of GFP DNA plasmid with $0.5 \mu \mathrm{g}$ of FAK shRNA plasmid or $0.5 \mu \mathrm{g}$ of Control-A shRNA (Santa Cruz) plasmid with $0.5 \mu \mathrm{g}$ of GFP DNA plasmid), a genetic strategy successfully used previously for the inhibition of FAK and other proteins [17-21]. Standardized confocal microscopy was performed 24 or $48 \mathrm{~h}$ after transfection for either FAK overexpression or inhibition.

\section{Cell Viability Assay}

Cell viability was monitored using the colorimetric MTT assay, as previously described [30]. Briefly, cells cultured in 96-well plates were treated with increasing concentrations of Y15 $(0.5,1$, $2,6,10,40 \mu \mathrm{M})$ or media alone as control and incubated with 0.5 $\mathrm{mg} / \mathrm{ml} \mathrm{MTT-Formazan} \mathrm{(Sigma),} \mathrm{at} 37^{\circ} \mathrm{C}$ under $5 \% \mathrm{CO}_{2}$, for $1 \mathrm{~h}$ and then washed in PBS. The blue Formazan reduction product, produced by the action of succinate dehydrogenase in living cells on the dye, was dissolved in $200 \mu \mathrm{l}$ DMSO, incubated for $10 \mathrm{~min}$ and the optical density was read at $550 \mathrm{~nm}$ using a BioTek Ultra Microplate Reader BL808 (BioTek Inc., Winooski, Vt., USA). Data are expressed as the percentage of viable cells compared with control cells (100\% viability) determined by MTT reduction.

\section{Western Blotting}

Animals were sacrificed by neck dislocation $4 \mathrm{~h}$ after termination of behavioral experiments. The hippocampus was rapidly dissected, snap-frozen in liquid nitrogen and the tissue was stored at $-80^{\circ} \mathrm{C}$ until use. Hippocampal tissue ( $\mathrm{n}=6-8$ per group) was ground under liquid nitrogen and homogenized in a protein lysis buffer containing of $10 \mathrm{mM}$ Tris- $\mathrm{HCl}$ ( $\mathrm{pH} 7.5), 150 \mathrm{mM} \mathrm{NaCl}$, $0.05 \%$ SDS, $0.5 \%$ Triton X-100, $1 \mathrm{mM}$ PMSF and protease inhibitor cocktail $(1 \times)$ (Roche Diagnostics, Mannheim, Germany). Western blotting was carried out essentially as previously described [31]. Membranes were blocked by incubating with 5\% non-fat dry milk in $100 \mathrm{~mm}$ Tris $\mathrm{pH} 7.5,150 \mathrm{mM} \mathrm{NaCl}$ and $0.1 \%$ Tween 20 (TTBS). Membranes were then incubated with primary antibodies (Phospho-FAK (Tyr397) [1:500], Cell Signaling Technology; total FAK [1:1,000], Cell Signaling Technology; phospho-PYK2 [1:500], Cell Signaling Technology; total PYK2 [1:500], Cell Signaling Technology; drebrin [1:1,000], MBL International, Wo- burn, Mass., USA; PSD95 [1:1,000], Millipore; synapsin I [1:1,000], Abcam plc, Cambridge, UK; Anti-Erk1/2 (p44/p42) [1:500], Millipore; Anti-phospho-MAP Kinase1/2 (Erk1/2) [1:500], Millipore) overnight at $4^{\circ} \mathrm{C}$, rinsed three times with TTBS and incubated $1 \mathrm{~h}$ at $21 \pm 1^{\circ} \mathrm{C}$ with horseradish peroxidase-conjugated secondary antibody (goat-anti rabbit IgG [1:3,000], Cell Signaling Technology; horse-anti mouse IgG [1:3,000], Cell Signaling Technology). Immunoreactivity was visualized by enhanced chemiluminescence (Amersham Biosciences, Piscataway, N.J., USA). Quantification was performed by chemiluminescent imaging with a FluorChem HD2 (Alpha Innotech, San Leandro, Calif., USA) using the respective software.

\section{Single-Cell Recordings and Data Analysis}

For recording of miniature excitatory postsynaptic currents (mEPSCs), mouse primary hippocampal neurons 14 days after plating were used. Cells were untreated (control), treated with $2 \mu \mathrm{M}$ Y15 $30 \mathrm{~min}$ prior to recording, incubated with NGF (25 ng/ $\mathrm{ml}) 24 \mathrm{~h}$ prior to recordings or treated with $2 \mu \mathrm{M}$ of Y15 for $30 \mathrm{~min}$ and after washout incubated with NGF $(25 \mathrm{ng} / \mathrm{ml})$ for $24 \mathrm{~h}$ before recordings. mEPSCs were acquired in the whole-cell configuration of the patch-clamp technique at room temperature $\left(21 \pm 1^{\circ} \mathrm{C}\right)$ on neurons at 14 days in vitro. The neurons were clamped at $-70 \mathrm{mV}$. The extracellular solution contained $140 \mathrm{~mm} \mathrm{NaCl}, 6 \mathrm{mM} \mathrm{KCl}$, $3 \mathrm{mM} \mathrm{CaCl}_{2}, 2 \mathrm{~mm} \mathrm{MgCl}, 29 \mathrm{~mm}$ glucose and $10 \mathrm{~mm}$ Hepes, and was adjusted to $\mathrm{pH} 7.4$ with $\mathrm{NaOH}$. $0.5 \mu \mathrm{M}$ tetrodotoxin and was added to inhibit sodium-channel conductance and prevent the occurrence of action potential propagations. $30 \mu \mathrm{M}$ bicucullinemethiodide was used to suppress miniature inhibitory postsynaptic currents. Recording electrodes from borosilicate glass capillaries were pulled using a horizontal puller (Sutter Instruments) to yield tip resistances of 2.5-5 $\mathrm{M} \Omega$ and filled with a solution containing $140 \mathrm{~mm} \mathrm{KCl}, 1.6 \mathrm{mM} \mathrm{CaCl}_{2}, 10 \mathrm{~mm}$ EGTA, $10 \mathrm{~mm}$ Hepes and $2 \mathrm{mM} \mathrm{Mg}$-ATP, adjusted to $\mathrm{pH} 7.3$ with $\mathrm{KOH}$. Events $<5 \mathrm{pA}$ and events with a slow rise time ( $>5 \mathrm{~ms}$ ) were excluded from the analysis. Currents were measured using the FitMaster software package (Heka Electronics). All data are given as means \pm SE.

\section{Brain Slice Preparation}

Brain slice preparations and electrophysiological experimental protocols were performed as previously described $[32,33]$ with minor modifications. In brief, male (7-11 weeks old) C57BL/6J mice (Janvier, France) were sacrificed by cervical dislocation. Brains were rapidly removed and immersed in cold $\left(\sim 4^{\circ} \mathrm{C}\right)$ artificial cerebrospinal fluid (ACSF). Hippocampi were isolated while submerged in ACSF and transverse slices $(400 \mu \mathrm{m})$ were prepared using a McIlwain Tissue Chopper (Mickle Laboratory Engineering Co. Ltd, Guilford, UK). Slices were transferred to a homemade nylon-mesh plastic holder floating in a home-made interface chamber containing ACSF maintained at $21 \pm 1^{\circ} \mathrm{C}$. Slices were allowed to recover for $1 \mathrm{~h}$ at $21 \pm 1^{\circ} \mathrm{C}$ plus 30 extra minutes at $28^{\circ} \mathrm{C}$ before recordings were performed. During the whole procedure, slices in ACSF were continuously supplied with a saturating Carbogen mixture $\left(95 \% \mathrm{O}_{2} / 5 \% \mathrm{CO}_{2}\right)$ leading to a $\mathrm{pH}$ of 7.4. Slices were then transferred to the recording chamber perfused with carbogenated ACSF at a rate of $2 \mathrm{ml} / \mathrm{min}$ and measurements were performed at a temperature of $28^{\circ} \mathrm{C}$. ACSF contained (in $\mathrm{mM}$ ): $\mathrm{NaCl} 125, \mathrm{KCl} 2.5, \mathrm{NaHCO}_{3} 25, \mathrm{CaCl}_{2} 2, \mathrm{MgCl}_{2} 1$, D-glucose 25, and $\mathrm{NaH}_{2} \mathrm{PO}_{4} 1.25$ (all from Sigma-Aldrich, Austria). 


\section{Slice Electrophysiology and Data Analysis}

Slice electrophysiology was performed essentially as previously described $[32,33]$ with minor modifications. Extracellular measurements of field excitatory postsynaptic potentials (fEPSPs) were performed by placing the recording electrode in the CA1 stratum radiatum of the hippocampus using borosilicate glass micropipettes (2-5 M $\Omega$ ) filled with ACSF. Data acquisition and storage were performed using an AxoClamp-2B amplifier in the Bridge mode, a Digidata 1440 interface and the pClamp-10 Program software (all from Axon Instruments, Foster City, Calif., USA/Molecular Devices, USA). fEPSPs were evoked by electrical stimulation of the Schaffer collateral/associational commissural pathway with a home-customized bipolar tungsten electrode insulated to the tip (50- $\mu \mathrm{m}$ tip diameter). Stimuli were delivered every $15 \mathrm{~s}$. The initial slope of the rising phase (20-80\% of peak amplitude) of the fEPSPs was used as a measure of the strength of synaptic transmission [32, 33]. Baseline recordings were taken using stimulation intensities eliciting $\sim 40 \%$ of the maximal obtainable response. Baselines comprised a minimum of $15 \mathrm{~min}$ of stable baseline recordings ( $5 \mathrm{~min}$ before theta-burst stimulations are shown). After theta-burst stimuli were applied to the Schaffer collateral/associational commissural pathway, elicited field recordings were obtained for at least $30 \mathrm{~min}$. Slope values for each obtained fEPSPs were then normalized with respect to the initial steady baseline responses recorded during the 5 min preceding the theta-burst stimulation. Test stimuli (50- $\mu$ s pulse width) were delivered every $15 \mathrm{~s}$. LTP was induced using a theta-burst stimulation protocol previously described [34].

\section{Behavioral Analysis}

Y15 (2 mg/kg) or saline were injected intraperitoneally in an injection volume of $10 \mathrm{ml} / \mathrm{kg}$ and behavioral analysis was carried out $30 \mathrm{~min}$ after injection.

Basic Neurological Examination

The procedure followed the set-up by Irwin [35]. A battery of tests was applied to reveal defects in gait or posture, changes in muscle tone, grip strength, visual acuity and temperature. To complete the assessment, vitally important reflexes were scored. Throughout the manipulations, incidences of abnormal behavior, fear, irritability, aggression, excitability, salivation, lacrimation, urination and defecation were recorded.

\section{Open Field}

The open field (OF) was a rectangular polyvinyl chloride arena $(30 \times 40 \times 60 \mathrm{~cm})$. Locomotor activity was recorded during 15 min using a CCD camera and analyzed using the Limelight video tracking system (Limelight Actimetrics, Elmwood, Ill., USA). Total distance traveled $(\mathrm{cm})$ as parameter for locomotor activity was automatically generated by the software. The equipment was cleaned using $70 \%$ ethanol between animals.

\section{Morris Water Maze}

The Morris water maze (MWM) consisted of a circular pool (122 cm diameter, walls $76 \mathrm{~cm}$ depth) in which mice were trained to escape from water by swimming to a hidden platform $(1.5 \mathrm{~cm}$ beneath the water surface) whose location could be only identified using distal extra-maze cues attached to the room walls. Visual cues had different colors and dimensions and were kept constant during the whole experiment. Water temperature was maintained at $21 \pm 1^{\circ} \mathrm{C}$. The pool was divided into four quadrants by a com- puterized tracking/image analyzing system (Limelight Actimetrics). The platform was placed in the middle of the SW quadrant and remained at the same position during the acquisition phase (training). The acquisition phase consisted of 12 training trials: 3 training trials per day and 5 training days with an inter-trial interval of $60 \mathrm{~min}$. Mice were injected with Y15 or saline $30 \mathrm{~min}$ before the first training trial on each day. Mice were released randomly with their heads facing the pool wall from the four compass locations (NE, NW, SW, and SE), and allowed to swim and search for the platform for $120 \mathrm{~s}$. If mice did not locate the platform after $120 \mathrm{~s}$, they were manually placed on the platform and allowed to remain on it for $15 \mathrm{~s}$. On the first training day, mice were given an acclimatization training session in which they were placed on the hidden platform, allowed to swim for $30 \mathrm{~s}$, and then subsequently guided back to the platform. The day after the acquisition phase, mice underwent a probe trial in which the platform was removed. Animals were released from the longest distance to the platform and were allowed to swim freely for $60 \mathrm{~s}$. The path the mouse swam was tracked and analyzed for the proportion of swimming time and/or path length spent in each quadrant of the pool was recorded.

\section{Statistical Analysis}

For comparisons between two groups, two-tailed Student's t tests and Fisher's exact test were used. Two-way ANOVAs were employed to assess the effects of NGF and Y15 in a $2 \times 2$ design. LTP data and latencies in the MWM were analyzed by repeated measures ANOVAs, with time points or training days respectively, as the repeated measure (within-subject factor) and pharmacological treatment as between-subject factor. Significant main effects or interactions were followed by Scheffé's post hoc test. An $\alpha$ level of 0.05 was adopted in all instances. All analyses were carried out using BioStat 2009 professional software (AnalystSoft Inc., Alexandria, Va., USA).

\section{Results}

\section{FAK Is Required for Neuritic Outgrowth in Mouse Hippocampal Neurons}

We started evaluating the involvement of FAK in neuritic outgrowth by examining the effects of pharmacological inhibition FAK on NGF-induced enhancement of the number and length of extensions of neuritic processes of mouse hippocampal neurons in culture. To this aim, Y15 was used at non-cytotoxic concentrations $(1 \mu \mathrm{M}$, cell viability $88.89 \%$ of control cells as revealed by the MTT assay) to block FAK activity. FAK inhibition by application of $1 \mu \mathrm{M}$ Y15 significantly impaired the growth enhancement induced by NGF evaluated by the average length of neuritic extensions, as revealed by two-way ANOVA (effect of Y15: $\left.F_{(1,55)}=16.29: \mathrm{p}<0.001\right)$ and the number of neuritic processes longer than $22.5 \mu \mathrm{m}$ (effect of Y15: $F_{(1,55)}=15.93$; $\mathrm{p}<0.001)$. FAK blockade induced by $\mathrm{Y} 15$ also significantly reduced the total number of neuritic extensions $\left(F_{(1,55)}=\right.$ $10.09 ; \mathrm{p}<0.01)$ (fig. $1 \mathrm{~A}-\mathrm{D})$. Y15 at a lower dosage $(0.5 \mu \mathrm{M})$ 


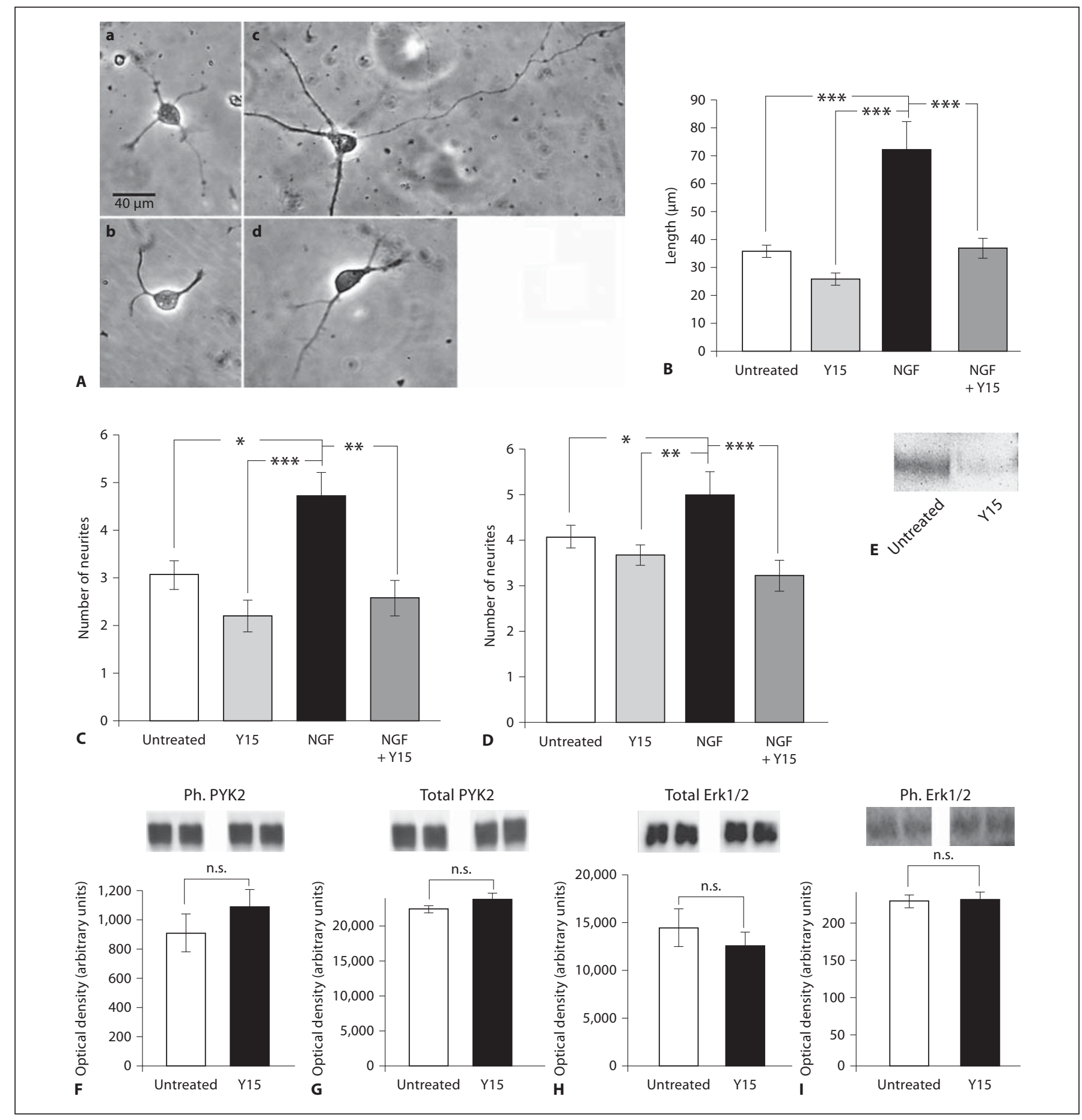

Fig. 1. FAK is required for neuritic outgrowth induced by NGF. A Y15 treatment results in a reduction of promotion of growth of neuritic processes induced by NGF in mouse hippocampal neurons: mouse hippocampal neurons without stimulation (a), after treatment with Y15 (b), after treatment with NGF (c), and after treatment with NGF in the presence of Y15 (d). The average length of neuritic extensions (B), the number of neuritic processes longer than $22.5 \mu \mathrm{m}(\mathbf{C})$, and the total number of neuritic extensions (D) are enhanced by treatment with NGF and reduced in the presence of Y15. E Treatment with Y15 reduces levels of Y397 phosphorylated FAK in mouse hippocampal neurons. Hippocampal protein levels of phosphorylated (Ph.) PYK2 (F), total PYK2 (G), total ERK1/2 (H), and phosphorylated (Ph.) ERK1/2 (I) are not affected by in vivo Y15 treatment. Protein levels are displayed as optical densities in arbitrary units. All data are displayed as mean \pm SEM. Statistical evaluation resulting from post hoc analysis is depicted. ${ }^{*} \mathrm{p}<0.05,{ }^{* *} \mathrm{p}<0.01,{ }^{* * *} \mathrm{p}<0.001$. n.s. = Not significant. 
did not affect neuritic outgrowth, while, in agreement with the MTT assay, higher dosages (6 and $10 \mu \mathrm{M})$ were not compatible with survival of hippocampal neurons (see online suppl. fig. S1; for all online suppl. material, see www. karger.com/doi/10.1159/000330193).

The inhibitory effect of Y15 on FAK activity in our experimental conditions was revealed by reduced phosphorylation levels of Y397 FAK in hippocampal cells as evaluated by Western blot (a representative image of three independent experiments is depicted in fig. 1E). The specificity of Y15 as selective inhibitor of FAK over other protein kinases was tested in mouse hippocampal tissue after in vivo treatment with $\mathrm{Y} 15(2 \mathrm{mg} / \mathrm{kg})$. No significant differences in the protein levels of phosphorylated and total PYK2 and phosphorylated and total Erk1/2 were detected (fig. 1F-I).

To further test the role of FAK in the morphological properties of hippocampal neurons using a genetic approach, we examined the effects of inhibition of FAK on neuritic outgrowth using specific FAK shRNA following a silencing genetic strategy used previously with success during the inhibition of FAK and other proteins [17-21]. Cotransfection of FAK shRNA plasmid and GFP plasmid resulted in a significant reduction in the total length and number of neurites per cell when compared to data obtained from cells cotransfected with scrambled control shRNA and GFP plasmids ( $\mathrm{p}<0.05$; fig. $2 \mathrm{~A}-\mathrm{C}$ ).

A gain-of-function experiment was then carried out to evaluate the effects of FAK overexpression on hippocampal neurons' neuritic outgrowth. Overexpression of FAKGFP resulted in a significant enhancement in the total length and number of neuritic extensions per cell when compared to neurons expressing GFP alone ( $p<0.001$; fig. 2D-F). Although specific FAK shRNAs have been proven to constitute an effective method to hinder FAK expression [17-21], we nevertheless examined this effectiveness in our experimental conditions. To this aim, we examined by immunocytochemistry the changes in signal detection in hippocampal neurons transfected with either FAK shRNA or scrambled control shRNA. Lower detection signals in cells transfected with FAK shRNA were observed (fig. 2G).

FAK Regulates Spontaneous Neurotransmitter Release of Hippocampal Neurons

To determine the possible role of FAK in regulating besides growth - also the electrophysiological properties of hippocampal neurons, we first tested the effect of Y15 on spontaneous neurotransmitter release and on its modulation induced by NGF. To this aim, we measured by single-cell voltage clamp the frequency and amplitude of mEPSCs in cultured hippocampal neurons treated with either NGF or Y15, or a combination of both. While NGF increased the frequency but not the amplitude of mEPSCs with respect to control cultures, treatment with Y15 significantly decreased the frequency of mEPSCs (effect of Y15: $\left.F_{(1,43)}=48.36 ; \mathrm{p}<0.0001\right)$ (fig. 3A, B) and of their amplitude $\left(F_{(1,43)}=51.36: \mathrm{p}<0.0001\right)$ (fig. $\left.3 \mathrm{~A}, \mathrm{C}\right)$. Taken together, these findings show that FAK activity regulates spontaneous neurotransmitter release and that this kinase is a key mediator of the effect of NGF on the frequency of mEPSCs.

\section{Inhibition of FAK Impairs Activity-Dependent LTP in Hippocampal Slices}

Given the evidence that FAK modulates spontaneous neurotransmitter release of hippocampal neurons, we investigated its possible role as a mediator of hippocampal synaptic plasticity at the network level. To this aim we measured fEPSPs in the CA1 dendritic layer of hippocampal slices induced by stimulation of the Schaffer collateral pathway, before and after high-frequency thetaburst stimulation. Y15 treatment did not prevent the theta-burst-induced post-tetanic potentiation but resulted in a significant impairment of the LTP $\left(F_{(1,12)}=4.98, \mathrm{p}<\right.$ 0.05 ) (fig. $4 \mathrm{~A}$ ) as also reflected in a reduction in fold change from baseline at 15 and 30 min after LTP induction (fig. 4B, C). These results indicate that FAK has a fundamental role in the long-term maintenance of hippocampal activity-dependent synaptic plasticity.

\section{Inhibition of FAK Impairs Hippocampus-Dependent \\ Spatial Learning and Memory}

Hippocampal LTP is one of the neural substrates of long-term memory formation [36-39]. Our observations of the involvement of FAK in the Schaffer collateral-CA1 hippocampal LTP, together with previous observations [40], prompted us to further explore in vivo the potential role of FAK in hippocampus-dependent learning and memory. To this aim, we used the MWM to study the effect of Y15-induced FAK inhibition on hippocampus-dependent spatial learning and memory. We found that, at a dosage of $2 \mathrm{mg} / \mathrm{kg}$, Y15 did not significantly alter basic neurological parameters of mice as evaluated by the Irwin observational battery [35] (table 1), while still leading to a significant reduction in Y397 phosphorylation of FAK in the hippocampus (fig. 5A) without affecting protein levels of total FAK (fig. 5B). Thirty minutes after injection with either $\mathrm{Y} 15$ or saline, control mice $(\mathrm{n}=10$ per group) underwent evaluation of locomotor and explor- 


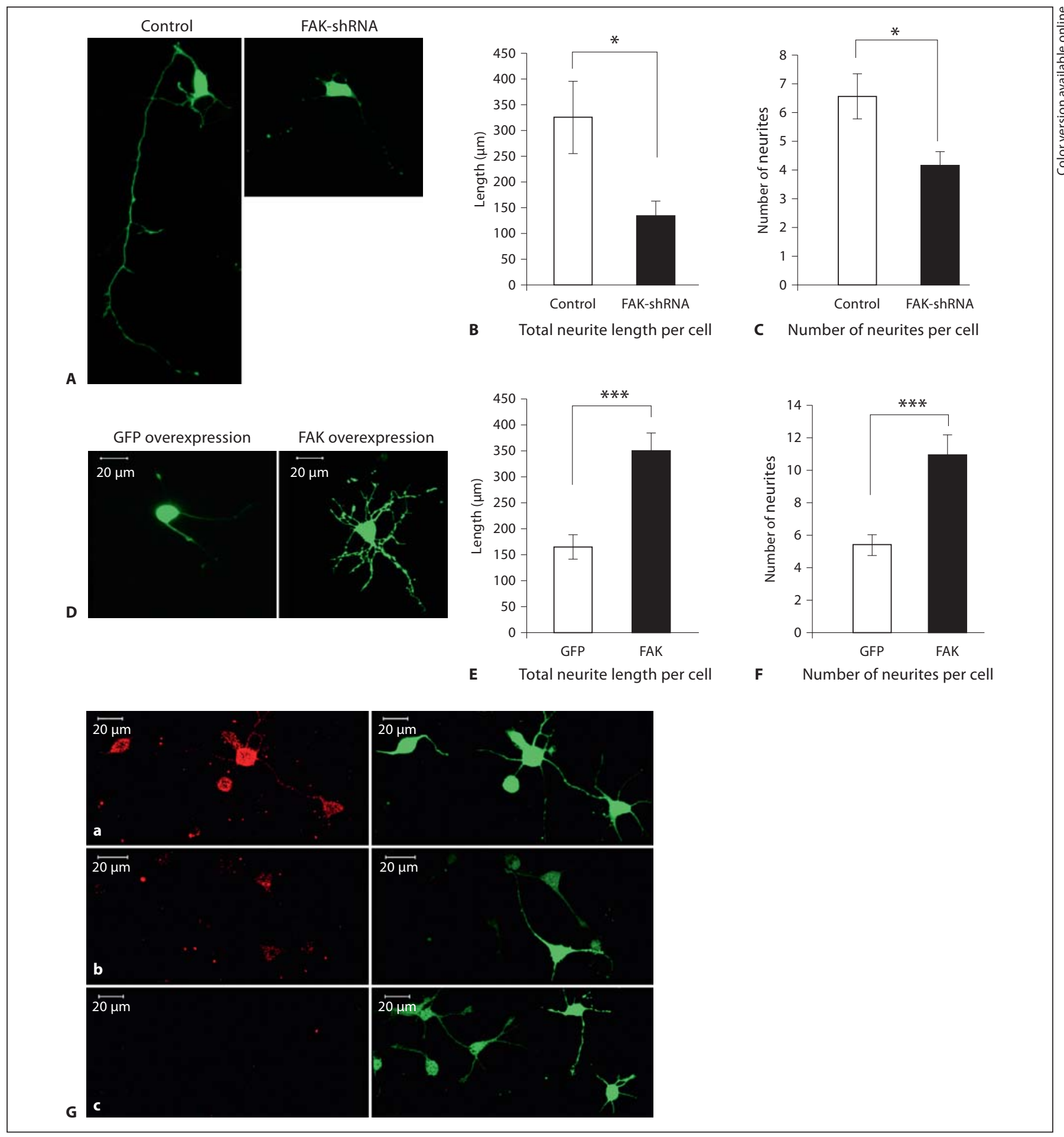

Fig. 2. FAK regulates neuritic outgrowth and interacts with neurotrophic tyrosine kinase receptor type 1 (TrkA). A Transfection of shRNA plasmids encoding plus hairpin sequences corresponding to FAK siRNA Gene Silencer sequences reduces neuritic outgrowth in mouse hippocampal neurons as evaluated by the length of all neurites (B) and the number of neurites per cell (C). D Expression of a FAK-GFP containing plasmid enhances neuritic out- growth in mouse hippocampal neurons as evaluated by the length of all neurites $(\mathbf{E})$ and the number of neurites per cell (F). G FAK shRNA is effective to obstruct FAK. Specific phospho-FAK antibody was used to detect signal levels in hippocampal neurons transfected with either scrambled control shRNA (a) or FAK shRNA (b); c negative control using secondary antibody alone. ${ }^{*} \mathrm{p}<0.05,{ }^{* * *} \mathrm{p}<0.001$. 
Fig. 3. FAK modulates miniature excitatory postsynaptic currents in mouse hippocampal neurons (mEPSCs). A Traces of recordings from mouse hippocampal neurons displaying mEPSCs in control cells (a), cells treated with Y15 (b), cells treated with NGF (c), and cells treated with NGF and Y15 (d). mEPSCs frequencies (B) and amplitudes (C) in control cells, cells treated with Y15, cells treated with NGF, and cells treated with NGF and Y15. All data are displayed as mean \pm SEM. Statistical evaluation resulting from post hoc analysis is depicted. ${ }^{* *} \mathrm{p}<0.001$.

Fig. 4. Inhibition of FAK impairs LTP in mouse hippocampal slices. A Field potential (fEPSP) slopes in mouse hippocampal slices treated with Y15 (grey squares) and untreated controls (black diamonds). Fold changes in response to theta-burst stimulation are depicted. Statistically significant differences in changes of fEPSP slope are observed $15 \mathrm{~min}(\mathbf{B})$ and $30 \mathrm{~min}(\mathbf{C})$ after theta-burst stimulation. All data are displayed as mean \pm SEM. Statistical evaluation resulting from repeated measure analysis $(\mathbf{A})$ and post hoc analysis $(\mathbf{B}, \mathbf{C})$ is depicted. ${ }^{*} \mathrm{p}<0.05,{ }^{* * *} \mathrm{p}<0.001$. a

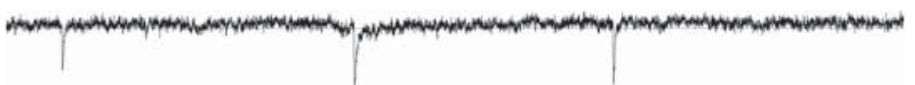

b
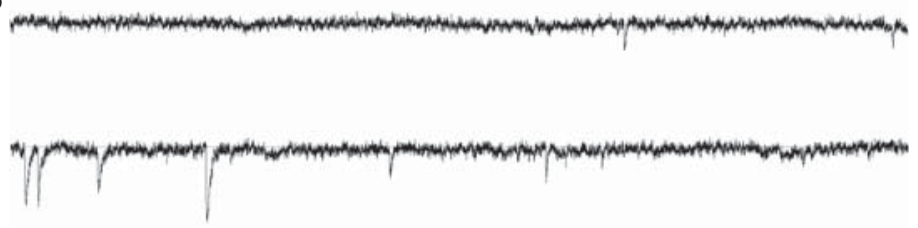

d

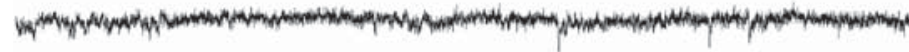

A
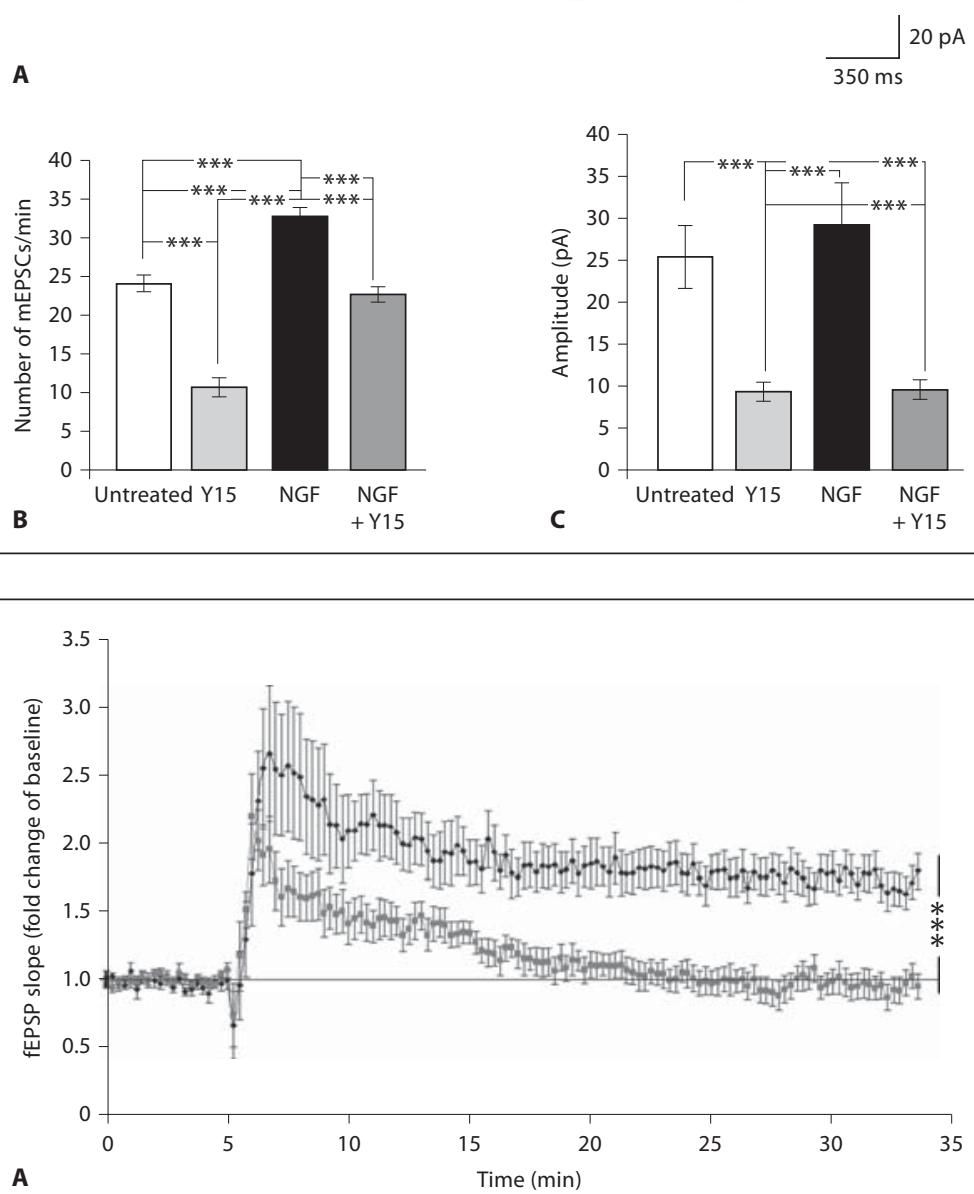

A
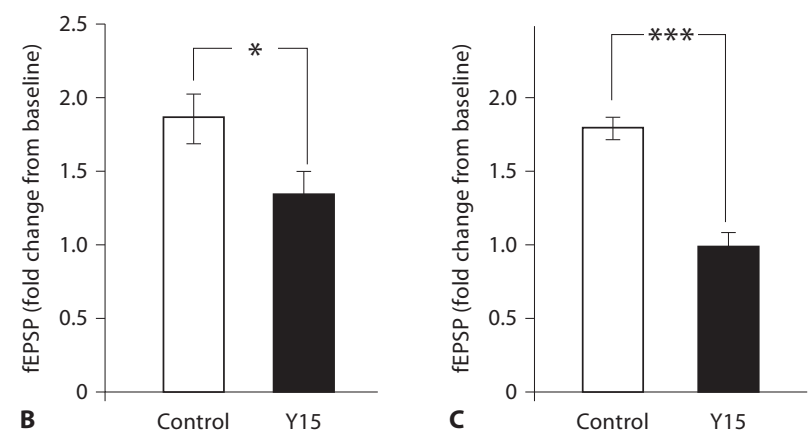


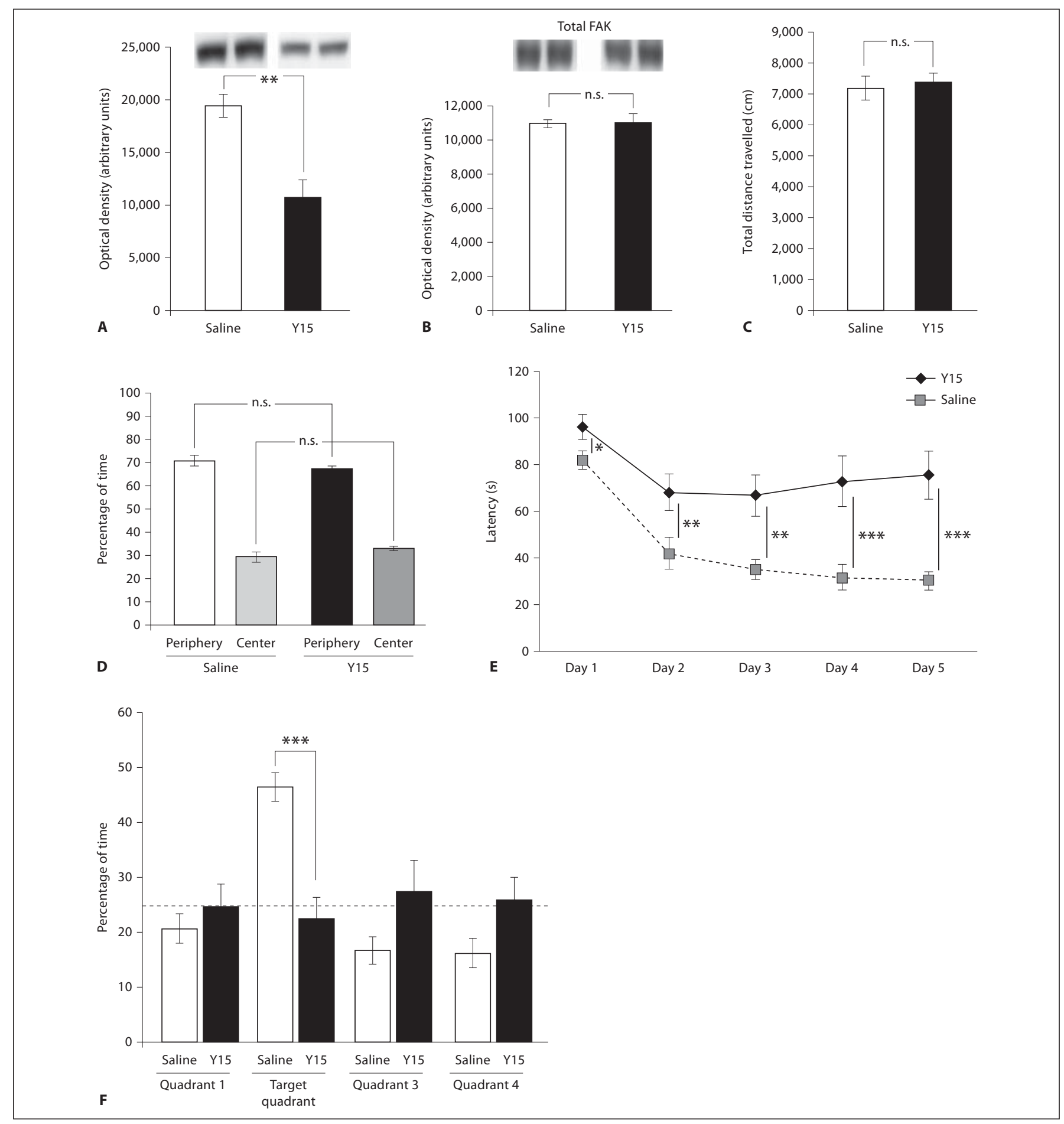

Fig. 5. Inhibition of FAK impairs hippocampus-dependent spatial learning and memory. Protein levels of Y397 phosphorylated FAK (A) and total FAK (B) in hippocampal tissue of Y15-treated (2 mg/ $\mathrm{kg}$ ) and saline control mice. Protein levels are displayed as optical densities in arbitrary units. Total distance traveled (C) and time spent (D) in the center and in the periphery in the OF in Y15treated and saline control mice. $\mathbf{E}$ Latency to find the hidden platform in the MWM during 5 days of training (average of three tri-

als per day) in Y15-treated and saline control mice. F Percentage of time spent in the target quadrant (original location of the platform during training) versus the other three quadrants during the probe trial in Y15-treated and saline control mice. Data are displayed as mean \pm SEM. Statistical evaluation resulting from pairwise comparison and post hoc analysis is depicted. ${ }^{*} \mathrm{p}<0.05$, ${ }^{* *} \mathrm{p}<0.01,{ }^{* * *} \mathrm{p}<0.001$. n.s. $=$ Not significant. 
Table 1. Results of the primary behavioral observation screen in Y15-treated and saline control mice

\begin{tabular}{|c|c|c|}
\hline & Saline & Y15 \\
\hline \multicolumn{3}{|c|}{ Muscle/lower motor neuron and spinocerebellar function } \\
\hline Body position & $5.9 \pm 0.3$ & $5.8 \pm 0.3$ \\
\hline Atactic gait & 0 & 0 \\
\hline Hypotonic gait & 0 & 0 \\
\hline Impaired gait & 0 & 0 \\
\hline Limb rotation & 0 & 0 \\
\hline Spatial locomotion & $2.1 \pm 0.6$ & $1.8 \pm 0.3$ \\
\hline Locomotor activity & $4.3 \pm 0.4$ & $4.1 \pm 0.5$ \\
\hline Wire maneuver & $1.0 \pm 0.4$ & $0.7 \pm 0.4$ \\
\hline Pelvic elevation & $2.0 \pm 0.3$ & $2.1 \pm 0.1$ \\
\hline Tail elevation & $3.4 \pm 0.5$ & $4.4 \pm 0.7$ \\
\hline Visual placing & $4.3 \pm 0.6$ & $4.4 \pm 0.5$ \\
\hline Abdominal tone & $3.8 \pm 0.4$ & $3.5 \pm 0.5$ \\
\hline Limb tone & $3.8 \pm 0.4$ & $3.1 \pm 0.5$ \\
\hline Grip strength & $4.4 \pm 0.9$ & $4.5 \pm 0.8$ \\
\hline Vestibular drop & 1 & 1 \\
\hline Proprioception & 1 & 1 \\
\hline \multicolumn{3}{|l|}{ Sensory function } \\
\hline Transfer arousal & $4.2 \pm 0.6$ & $4.3 \pm 0.7$ \\
\hline Pinna reflex & $3.8 \pm 0.4$ & $3.5 \pm 0.7$ \\
\hline Corneal reflex & $3.7 \pm 1.4$ & $3.3 \pm 0.9$ \\
\hline Tail pinch & $2.8 \pm 1.0$ & $2.6 \pm 0.5$ \\
\hline Toe pinch & $1.8 \pm 0.3$ & $1.3 \pm 0.4$ \\
\hline Finger approach & $1.9 \pm 0.5$ & $1.7 \pm 0.6$ \\
\hline Finger withdrawal & $3.9 \pm 0.6$ & $3.6 \pm 0.5$ \\
\hline \multicolumn{3}{|l|}{ Neuropsychiatric function } \\
\hline Bizarre behavior & 0 & 0 \\
\hline Tremor/twitches & 0 & 0 \\
\hline Provoked biting & 0 & 0 \\
\hline Provoked freezing & 0 & 0 \\
\hline Biting tendency & $2.5 \pm 0.8$ & $2.3 \pm 0.9$ \\
\hline \multicolumn{3}{|l|}{ Autonomous function } \\
\hline Palpebral closure & 0 & 0 \\
\hline Skin color & $4.1 \pm 0.4$ & $4.3 \pm 0.8$ \\
\hline Respiratory rate & $4.5 \pm 0.4$ & $4.8 \pm 0.5$ \\
\hline Hypothermia & 0 & 0 \\
\hline Urination/defecation & $1.2 \pm 1.2$ & $1.2 \pm 0.5$ \\
\hline Salivation & 0 & 0 \\
\hline Piloerection & $1.9 \pm 0.5$ & $1.8 \pm 0.4$ \\
\hline
\end{tabular}

Scores (mean $\pm \mathrm{SD}$ ) as evaluated by Irwin [35]: higher score presents more (better, higher) activity (performance, response) or parameters are scored as present (1) or absent (0).

atory activity in the OF. No significant differences in total distance travelled ( $p>0.05$ ) (fig. 5C) and time spent in the center $(p>0.05)$ (fig. 5D) were observed among groups. Forty-eight hours after the OF test, mice of both groups were subjected to training in the MWM. Latency to reach the hidden platform averaged over three daily trials was used as parameter for spatial learning and memory. Significant differences between Y15-injected mice and saline controls were observed on all 5 days of training (effect of day of training $F_{(4,23)}=15.07$ : $\mathrm{p}<0.0001$, effect of $Y 15 F_{(1,26)}=28.68$ : p < 0.0001) (fig. 5E). Twentyfour hours after the last day of training, a probe trial in which the platform had been removed was carried out and the percentage of time spent in the quadrant which had originally contained the platform was used as indicator of spatial memory. While control mice showed a significant preference for the target quadrant, Y15-injected mice did not spend significantly more time in the target than in adjacent quadrants (fig. 5F). Taken together, these findings indicate that FAK activity is required for hippocampus-dependent spatial learning and for its long-term retention.

\section{FAK Inhibition Alters the Levels of Hippocampal Synaptic Proteins}

To evaluate the effects of FAK inhibition on synapse composition, levels of pre- and post-synaptic marker proteins were determined in hippocampal tissue of Y15treated and saline-treated control mice. A significant reduction of synapsin I ( $p<0.05)$, PSD-95 ( $p<0.01)$ and drebrin $(\mathrm{p}<0.01)$ protein levels induced by Y15 treatment was revealed by Western blot (fig. 6A-C).

\section{Discussion}

The results of our experiments indicate that the nonreceptor tyrosine kinase FAK is a fundamental player in the regulation of neuronal growth, synaptic function and plasticity of hippocampal neurons, as well as a necessary element for hippocampus-dependent spatial learning and memory.

\section{FAK and Hippocampal Neuronal Outgrowth}

Using both loss- and gain-of-function approaches, we here provide evidence that FAK plays a major role as a positive regulator of the morphological properties of hippocampal neurons. Our data suggest that FAK might act as mediator conveying the effects of neurotrophins, such as NGF, on cytoskeletal rearrangement underlying neuritic outgrowth, similarly as proposed for growth factors including platelet-derived and epidermal growth factors (PDGF and EGF, respectively) [41]. It has been shown that neuronal stimulation with NGF results in rapid and specific activation of both the FAK and the MAPK signaling pathways and that inhibition of FAK activity in this con- 


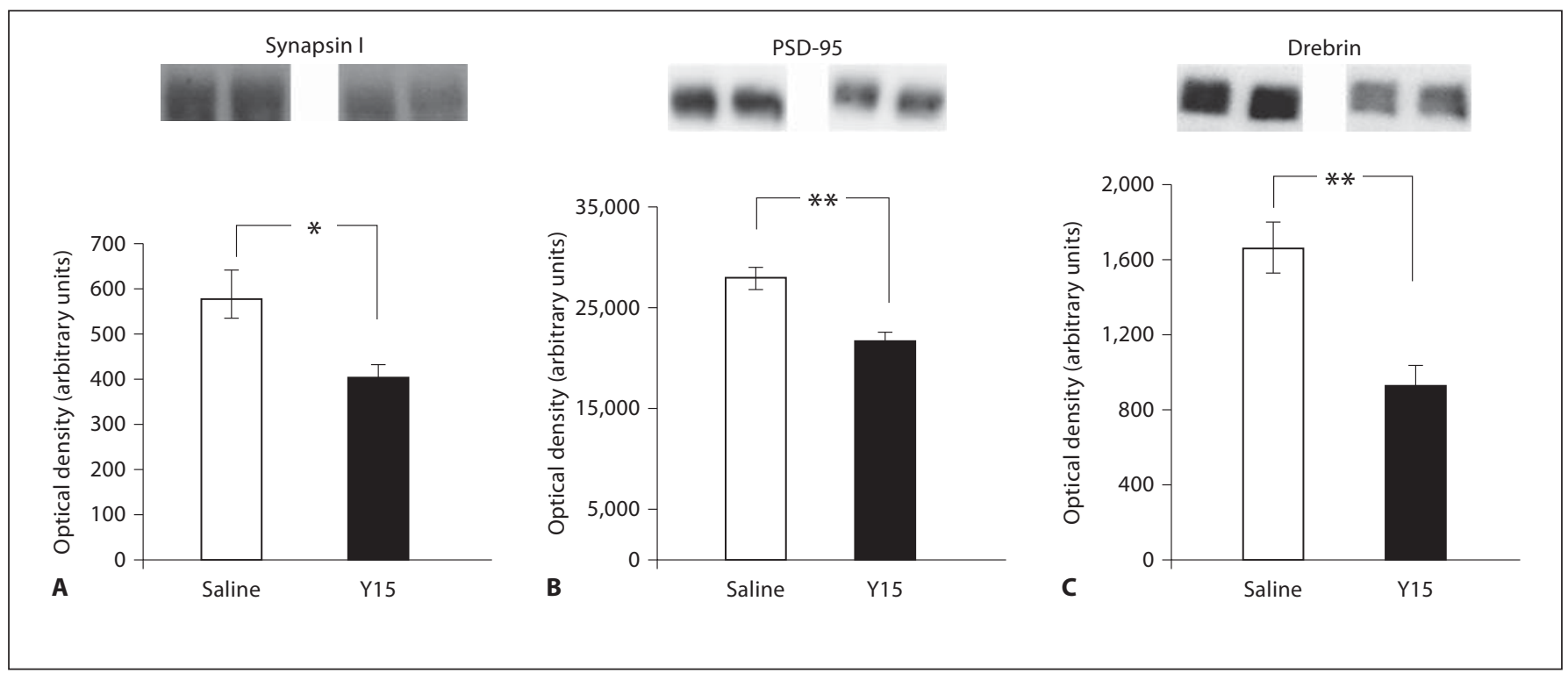

Fig. 6. Inhibition of FAK modulates levels of synaptic proteins in the mouse hippocampus. Synapsin I (A), PSD-95 (B) and drebrin (C) protein levels determined by Western blot experiments in hippocampal tissue of saline control and Y15-treated $(2 \mathrm{mg} / \mathrm{kg})$ mice. Protein levels are displayed as optical densities in arbitrary values. Data are displayed as mean \pm SEM. Statistical evaluation resulting from pairwise comparison is depicted. ${ }^{*} \mathrm{p}<0.05$, ${ }^{* *} \mathrm{p}<0.01$. text attenuates both NGF-induced PI3-K/Akt and MEK/ MAPK signaling pathways, as well as neurite growth [42]. Previous reports indicate that FAK is an important modulator of the NGF signaling pathway, suggesting the possibility that FAK might interfere with the regulation of TrkA receptor levels induced by NGF [43]. However, the specific mechanism linking the mediation of FAK in neurotrophin signaling still remains unclear. Our data indicate that FAK activity related to NGF signaling is importantly related to the modulation of structural properties of maturing neurons, morphological features which are prerequisites for memory-related synaptic activity in hippocampus [42].

\section{FAK as a Regulator of Hippocampal Synaptic}

Function and Plasticity

We found that FAK is an important regulator of spontaneous and evoked synaptic activity and plasticity in hippocampal neurons. Electrophysiological recordings in cultured hippocampal neurons revealed an important role for FAK as a mediator of both frequency and amplitude of spontaneous mEPSCs and as mediator of the NGF-dependent modulation of spontaneous release. The observation that FAK inhibition impacts on mEPSCs amplitude and the frequency suggests a role for FAK signaling in pre- and postsynaptic plasticity-related mecha- nisms. Postsynaptic modulation of growth factor and neurotrophin receptor function may account for the effect of FAK on mEPSCs amplitude. Moreover, FAK is also necessary for the EphB receptor tyrosine kinaseinduced formation of dendritic spines [16] and may thus impact postsynaptic architecture. Modifications of mEPSCs frequency point towards an involvement of FAK in the regulation of presynaptic neurotransmitter release probability. FAK is importantly involved in signaling pathways originating from integrin-mediated cell adhesions sites and cell adhesion molecules have been described to be required for excitatory synapse formation $[44,45]$ and to critically affect mEPSCs frequency [45]. Indeed, integrin signaling has been found to be important for coordinating exocytotic events [46] and disruption of FAK activity might partially impair the neuronal exocytotic machinery, thus hampering neurotransmitter release. Important roles for mEPSCs in the regulation of neuronal firing [47], synaptic plasticity [48], dendritic spine density [49] and local protein synthesis have been proposed [50]. Thus, FAK may contribute to these processes also through a regulation of spontaneous neurotransmitter release at hippocampal synapses.

Given the evidence provided by our morphological and electrophysiological studies on the involvement of 
FAK in hippocampal synaptic activity, we set out to investigate the role of this kinase in the plasticity of hippocampal synaptic circuits. A pioneering study has shown that FAK is required for the induction phase of LTP in the dentate gyrus of rats [40]. However, other aspects of FAK involvement in long-term plasticity in the hippocampal circuitry remain unexplored. We therefore studied here the role of FAK in the memory-related Schaffer collateralCA1 pathway. The results of our experiments show that inhibition of FAK does not affect basal synaptic transmission or high-frequency-induced post-tetanic potentiation but significantly impairs the protein synthesis-dependent maintenance phase of hippocampal LTP. Interestingly, the pioneering study on the involvement of FAK in hippocampal synaptic plasticity at the network level in the dentate gyrus also showed that inhibition of FAK activity resulted in a deficit of the protein synthesis-dependent induction of LTP [40]. Thus, our studies on the Schaffer collateral-CA1 neuronal pathway functionally complement the findings of the Yang et al. [40] study of the dentate gyrus. Together with our here first described in vivo studies, these findings point towards a general relevance of the role of FAK within the hippocampal formation and consequently in learning and memory formation and retention.

There are several possible mechanisms by which FAK inhibition may lead to impairment in the maintenance of Schaffer collateral-CA1 LTP. First, FAK is a scaffolding molecule which is known to form complexes with integrin receptors which convey signals from the extracellular matrix to the cytoskeleton [for a review, see 51]. In fact, the effects of integrin antagonists, preventing the establishment of a stable phase of synaptic potentiation after LTP induction [52], are similar to those observed herein after FAK inhibition. This observation suggests that deficient integrin signaling might contribute to the LTP impairment induced by inhibition of FAK. Moreover, FAK directly activates target proteins, such as neural WiskottAldrich syndrome protein (N-WASP), that are crucial regulators of the actin complex during the cytoskeletal reorganization required for the formation of dendritic spines [53]. Additionally, FAK is also required for the EphB receptor-modulated regulation of dendritic spine morphology through RhoA activation [16]. Considering the pivotal role of dendritic spines as postsynaptic terminals of excitatory synapses for synaptic plasticity, it can be hypothesized that deregulation of the molecular processes mediating spine formation, such as insufficient activation of N-WASP or RhoA, resulting from inhibition of FAK, may also contribute to altered LTP [16]. Third,
FAK is known as cellular partner for the Src family of protein kinases and FAK and Src are known to activate each other [for a review, see 54]. Inhibition of Src kinases has been shown to prevent potentiation of glutamatergic N-methyl-D-aspartate (NMDA) receptor-mediated transmission, critical for the stabilization of LTP at hippocampal synapses [55]. FAK inhibition might thus also disrupt NMDA receptor plasticity, ultimately affecting hippocampal LTP [4-6]. Finally, the effects of FAK on LTP may also be related to the interaction of FAK with the NGF/Trk pathway which we are indicating herein. In fact, it has been demonstrated that increase in the levels of NGF facilitate the induction of hippocampal LTP, and that blocking endogenous NGF results in a significant reduction of hippocampal LTP [56-58]. TrkA activation by NGF is also inhibited by treatment with an inhibitor of Src family kinases [55]. Since FAK and Src are capable of mutual activation [54] and given that activated Src can also phosphorylate TrkA directly in vitro [55], alterations of FAK activity might also impact LTP by regulating the heteromeric signaling complexes associated to the NGF/ TrkA pathway.

\section{FAK Is Involved in Hippocampus-Dependent Spatial Learning and Memory}

Since the role of FAK for learning and memory in vivo has not yet been determined, we here examined hippocampus-dependent spatial learning and memory in mice while pharmacologically inhibiting FAK activity as a final step in characterizing the role of FAK in synaptic plasticity. Our findings that FAK inhibition resulted in deficient learning in the MWM task, as well as in impaired retention and retrieval of the spatial memory, are well in line with our studies of spontaneous synaptic activity carried out on individual neurons and also in agreement with our results obtained from the LTP analysis of hippocampal slices, and therefore are most likely to be mediated by the same molecular mechanisms. Our data indicate that at dosages effectively inhibiting FAK activity, Y15 can be used as a valuable tool in the study of the physiological role of FAK in the nervous system and its involvement in memory-related synaptic plasticity.

By demonstrating reduced hippocampal levels of synaptic proteins, including synapsin I, a nerve terminalspecific synaptic vesicle-associated marker protein, the postsynaptic marker protein PSD-95 and the actin-binding protein drebrin, a marker for dendritic spines, we provide evidence that the involvement of FAK in hippocampal-mediated spatial memory formation and mainte- 
nance could be in part attributable to a participation of FAK in the regulation of synapse formation and composition. These data are also in agreement with results suggesting a functional link between the FAK and the NGF pathway in the regulation of both structural/morphological and electrical synapse-related properties of neurons. This first demonstration of a role for FAK in cognitive processes in the intact animal complements our results from morphological and functional analyses at the single cell and network level and allows a comprehensive evaluation about the role of FAK as critical positive regulator of learning-related synaptic plasticity in the mouse hippocampus.

\section{Acknowledgments}

The FAK-GFP construct was a generous gift from Dr. J. Thomas Parsons (University of Virginia Department of Microbiology, Va., USA). The GFP construct was a generous gift from Prof. Michael Kiebler (Center for Brain Research, Medical University of Vienna, Austria). We specially thank Fr. Sabine Thomas (Prof. Kiebler's laboratory) for expert advice on neuronal cultures. We thank Dr. Gerhard Rammes, Ing. Reiner Poldi and the NPI Company for expert scientific assistance with the electrophysiological methods. We also thank Dr. Renate Pflug, Prof. Peter Anhelt, Prof. Stefan Böehm and Prof. Michael Freissmuth at the Department of Neurophysiology and Neuropharmacology, Center for Physiology and Pharmacology of the University of Vienna, Austria, for valuable support. F.J.M. was supported by the HochschulJubiläum-Stiftung der Stadt Wien.

\section{References}

1 Kandel ER: The molecular biology of memory storage: a dialogue between genes and synapses. Science 2001;294:1030-1038.

$\checkmark 2$ Chao MV: Neurotrophins and their receptors: a convergence point for many signalling pathways. Nat Rev Neurosci 2003;4:299-309.

-3 Minichiello L, Calella AM, Medina DL, Bonhoeffer T, Klein R, Korte M: Mechanism of TRKB-mediated hippocampal long-term potentiation. Neuron 2002;36:121-137.

-4 Lauri SE, Kaukinen S, Kinnunen T, Ylinen A, Imai S, Kaila K, Taira T, Rauvala H: Regulatory role and molecular interactions of a cell-surface heparan sulfate proteoglycan (N-syndecan) in hippocampal long-term potentiation. J Neurosci 1999;19:1226-1235.

5 Lu YM, Roder JC, Davidow J, Salter MW: Src activation in the induction of long-term potentiation in CA1 hippocampal neurons. Science 1998;279:1363-1367.

6 Fernandez de Sevilla D, Buno W: The muscarinic long-term enhancement of NMDA and AMPA receptor-mediated transmission at Schaffer collateral synapses develop through different intracellular mechanisms. J Neurosci 2010;30:11032-11042.

-7 Grant SG, Karl KA, Kiebler MA, Kandel ER: Focal adhesion kinase in the brain: Novel subcellular localization and specific regulation by Fyn tyrosine kinase in mutant mice. Genes Dev 1995;9:1909-1921.

-8 Burgaya F, Menegon A, Menegoz M, Valtorta F, Girault JA: Focal adhesion kinase in rat central nervous system. Eur J Neurosci 1995; 7:1810-1821.

-9 Girault JA, Costa A, Derkinderen P, Studler $\mathrm{JM}$, Toutant M: FAK and PYK2/CAK $\beta$ in the nervous system: a link between neuronal activity, plasticity and survival? Trends Neurosci 1999;22:257-263.

10 Rico B, Beggs HE, Schahin-Reed D, Kimes N, Schmidt A, Reichardt LF: Control of axonal branching and synapse formation by fo- cal adhesion kinase. Nat Neurosci 2004;7: 1059-1069.

11 Diaz-Hernandez M, del Puerto A, Diaz-Hernandez JI, Diez-Zaera M, Lucas JJ, Garrido JJ, Miras-Portugal MT: Inhibition of the ATPgated $\mathrm{P} 2 \mathrm{X} 7$ receptor promotes axonal growth and branching in cultured hippocampal neurons. J Cell Sci 2008;121:3717-3728.

12 Liu G, Beggs H, Jurgensen C, Park HT, Tang H, Gorski J, Jones KR, Reichardt LF, Wu J, Rao Y: Netrin requires focal adhesion kinase and Src family kinases for axon outgrowth and attraction. Nat Neurosci 2004;7:1222-1232.

13 Ivankovic-Dikic I, Gronroos E, Blaukat A, Barth BU, Dikic I: PYK2 and FAK regulate neurite outgrowth induced by growth factors and integrins. Nat Cell Biol 2000;2:574581.

14 Shi Y, Pontrello CG, DeFea KA, Reichardt LF, Ethell IM: Focal adhesion kinase acts downstream of EPHB receptors to maintain mature dendritic spines by regulating cofilin activity. J Neurosci 2009;29:8129-8142.

15 Bourgin C, Murai KK, Richter M, Pasquale EB: The EPHA4 receptor regulates dendritic spine remodeling by affecting $\beta_{1}$-integrin signaling pathways. J Cell Biol 2007;178: 1295-1307.

16 Moeller ML, Shi Y, Reichardt LF, Ethell IM: EphB receptors regulate dendritic spine morphogenesis through the recruitment/ phosphorylation of focal adhesion kinase and RhoA activation. J Biol Chem 2006;281: 1587-1598.

17 Dun ZN, Zhang XL, An JY, Zheng LB, Barrett R, Xie SR: Specific shRNA targeting of FAK influenced collagen metabolism in rat hepatic stellate cells. World J Gastroenterol 2010;16:4100-4106.

18 Ghosh B, Li Y, Thayer SA: Inhibition of the plasma membrane $\mathrm{Ca}^{2+}$ pump by $\mathrm{CD} 44$ receptor activation of tyrosine kinases increases the action potential after hyperpolariza- tion in sensory neurons. J Neurosci 2011;31: 2361-2370.

19 Goh EL, Young JK, Kuwako K, Tessier-Lavigne M, He Z, Griffin JW, Ming GL: Beta-1integrin mediates myelin-associated glycoprotein signaling in neuronal growth cones. Mol Brain 2008;1:10

-20 Li YL, Wu GZ, Dawe GS, Zeng L, Cui SS, Loers G, Tilling T, Sun L, Schachner M, Xiao ZC: Cell surface sialylation and fucosylation are regulated by $\mathrm{L} 1$ via phospholipase $\mathrm{C} \gamma$ and cooperate to modulate neurite outgrowth, cell survival and migration. PLoS One 2008; 3:e3841.

21 Swiech L, Blazejczyk M, Urbanska M, Pietruszka P, Dortland BR, Malik AR, Wulf PS, Hoogenraad CC, Jaworski J: CLIP-170 and IQGAP1 cooperatively regulate dendrite morphology. J Neurosci 2011;31:4555-4568.

22 Beierle EA, Ma X, Stewart J, Nyberg C, Trujillo A, Cance WG, Golubovskaya VM: Inhibition of focal adhesion kinase decreases tumor growth in human neuroblastoma. Cell Cycle 2010;9:1005-1015.

23 Hochwald SN, Nyberg C, Zheng M, Zheng D, Wood C, Massoll NA, Magis A, Ostrov D, Cance WG, Golubovskaya VM: A novel small molecule inhibitor of FAK decreases growth of human pancreatic cancer. Cell Cycle 2009;8:2435-2443.

24 Perry BC, Wang S, Basson MD: Extracellular pressure stimulates adhesion of sarcoma cells via activation of focal adhesion kinase and AKT. Am J Surg 2010;200:610-614.

25 Zheng D, Golubovskaya V, Kurenova E, Wood C, Massoll NA, Ostrov D, Cance WG, Hochwald SN: A novel strategy to inhibit FAK and IGF-1R decreases growth of pancreatic cancer xenografts. Mol Carcinog 2010;49:200-209.

26 Nunez J: Primary culture of hippocampal neurons from P0 newborn rats. J Vis Exp 2008. 
27 Zeitelhofer M, Vessey JP, Xie Y, Tubing F, Thomas S, Kiebler M, Dahm R: High-efficiency transfection of mammalian neurons via nucleofection. Nat Protoc 2007;2:16921704.

28 Kawabe H, Neeb A, Dimova K, Young SM Jr, Takeda M, Katsurabayashi S, Mitkovski M, Malakhova OA, Zhang DE, Umikawa M, Kariya K, Goebbels S, Nave KA, Rosenmund C, Jahn O, Rhee J, Brose N: Regulation of Rap2A by the ubiquitin ligase Nedd4-1 controls neurite development. Neuron 2010;65:358372.

-29 Shirasu M, Kimura K, Kataoka M, Takahashi M, Okajima S, Kawaguchi S, Hirasawa Y, Ide C, Mizoguchi A: VAMP-2 promotes neurite elongation and SNAP-25A increases neurite sprouting in PC12 cells. Neurosci Res 2000; 37:265-275.

30 Mosmann T: Rapid colorimetric assay for cellular growth and survival: application to proliferation and cytotoxicity assays. J Immunol Methods 1983;65:55-63.

- 31 Pollak DD, Scharl T, Leisch F, Herkner K, Villar SR, Hoeger H, Lubec G: Strain-dependent regulation of plasticity-related proteins in the mouse hippocampus. Behav Brain Res 2005; 165:240-246.

-32 Simon W, Hapfelmeier G, Kochs E, Zieglgansberger W, Rammes G: Isoflurane blocks synaptic plasticity in the mouse hippocampus. Anesthesiology 2001;94:1058-1065.

-33 Rammes G, Starker LK, Haseneder R, Berkmann J, Plack A, Zieglgansberger W, Ohl F, Kochs EF, Blobner M: Isoflurane anaesthesia reversibly improves cognitive function and long-term potentiation via an upregulation in NMDA receptor 2B subunit expression. Neuropharmacology 2009;56:626-636.

34 Nguyen PV, Kandel ER: Brief theta-burst stimulation induces a transcription-dependent late phase of LTP requiring CAMP in area CA1 of the mouse hippocampus. Learn Mem 1997;4:230-243.

- 35 Irwin S: Comprehensive observational assessment: Ia. A systematic, quantitative procedure for assessing the behavioral and physiologic state of the mouse. Psychopharmacologia 1968;13:222-257.

-36 Tsien JZ, Huerta PT, Tonegawa S: The essential role of hippocampal CA1 NMDA receptor-dependent synaptic plasticity in spatial memory. Cell 1996;87:1327-1338.
37 Rose GM, Dunwiddie TV: Induction of hippocampal long-term potentiation using physiologically patterned stimulation. Neurosci Lett 1986;69:244-248.

38 Larson J, Wong D, Lynch G: Patterned stimulation at the theta frequency is optimal for the induction of hippocampal long-term potentiation. Brain Res 1986;368:347-350.

39 Bliss TV, Collingridge GL: A synaptic model of memory: long-term potentiation in the hippocampus. Nature 1993;361:31-39.

40 Yang YC, Ma YL, Chen SK, Wang CW, Lee $\mathrm{EH}$ : Focal adhesion kinase is required, but not sufficient, for the induction of long-term potentiation in dentate gyrus neurons in vivo. J Neurosci 2003;23:4072-4080.

-41 Sieg DJ, Hauck CR, Ilic D, Klingbeil CK, Schaefer E, Damsky CH, Schlaepfer DD: FAK integrates growth-factor and integrin signals to promote cell migration. Nat Cell Biol 2000;2:249-256.

42 Tucker BA, Rahimtula M, Mearow KM: Src and FAK are key early signalling intermediates required for neurite growth in NGF-responsive adult DRG neurons. Cell Signal 2008;20:241-257.

43 Holtzman DM, Li Y, Parada LF, Kinsman S, Chen CK, Valletta JS, Zhou J, Long JB, Mobley WC: p140trk MRNA marks NGF-responsive forebrain neurons: evidence that trk gene expression is induced by NGF. Neuron 1992;9:465-478.

44 Scheiffele P, Fan J, Choih J, Fetter R, Serafini $\mathrm{T}$ : Neuroligin expressed in nonneuronal cells triggers presynaptic development in contacting axons. Cell 2000;101:657-669.

45 Chen SX, Tari PK, She K, Haas K: Neurexinneuroligin cell adhesion complexes contribute to synaptotropic dendritogenesis via growth stabilization mechanisms in vivo. Neuron 2010;67:967-983.

46 Gupton SL, Gertler FB: Integrin signaling switches the cytoskeletal and exocytic machinery that drives neuritogenesis. Dev Cell 2010;18:725-736.

47 Sharma G, Vijayaraghavan S: Modulation of presynaptic store calcium induces release of glutamate and postsynaptic firing. Neuron 2003;38:929-939.

48 Murphy TH, Blatter LA, Bhat RV, Fiore RS, Wier WG, Baraban JM: Differential regulation of calcium/calmodulin-dependent protein kinase II and p42 MAP kinase activity by synaptic transmission. J Neurosci 1994 14:1320-1331.
49 McKinney RA, Capogna M, Durr R, Gahwiler BH, Thompson SM: Miniature synaptic events maintain dendritic spines via AMPA receptor activation. Nat Neurosci 1999;2: 44-49.

50 Sutton MA, Wall NR, Aakalu GN, Schuman EM: Regulation of dendritic protein synthesis by miniature synaptic events. Science 2004;304:1979-1983.

-51 Cox BD, Natarajan M, Stettner MR, Gladson CL: New concepts regarding focal adhesion kinase promotion of cell migration and proliferation. J Cell Biochem 2006;99:35-52.

52 Bahr BA, Staubli U, Xiao P, Chun D, Ji ZX, Esteban ET, Lynch G: Arg-Gly-Asp-Ser-selective adhesion and the stabilization of long-term potentiation: pharmacological studies and the characterization of a candidate matrix receptor. J Neurosci 1997;17: 1320-1329.

53 Wegner AM, Nebhan CA, Hu L, Majumdar D, Meier KM, Weaver AM, Webb DJ: NWASP and the ARP2/3 complex are critical regulators of actin in the development of dendritic spines and synapses. J Biol Chem 2008;283:15912-15920.

54 Hanks SK, Ryzhova L, Shin NY, Brabek J: Focal adhesion kinase signaling activities and their implications in the control of cell survival and motility. Front Biosci 2003;8:d982d996.

-55 Tsuruda A, Suzuki S, Maekawa T, Oka S: Constitutively active Src facilitates NGF-induced phosphorylation of TrkA and causes enhancement of the MAPK signaling in SKN-MC cells. FEBS Lett 2004;560:215-220.

56 Brooks AI, Cory-Slechta DA, Federoff HJ: Gene-experience interaction alters the cholinergic septohippocampal pathway of mice. Proc Natl Acad Sci USA 2000;97:1337813383.

57 Conner JM, Franks KM, Titterness AK, Russell K, Merrill DA, Christie BR, Sejnowski TJ, Tuszynski MH: Ngf is essential for hippocampal plasticity and learning. J Neurosci 2009;29:10883-10889.

58 Pesavento E, Capsoni S, Domenici L, Cattaneo A: Acute cholinergic rescue of synaptic plasticity in the neurodegenerating cortex of anti-nerve-growth-factor mice. Eur J Neurosci 2002;15:1030-1036. 